Tips om medisinsk litteratur, andre bøker, filmer og elektroniske medier som bør anmeldes, sendes tidsskriftet@legeforeningen.no

\section{Viktig bok om samliv}

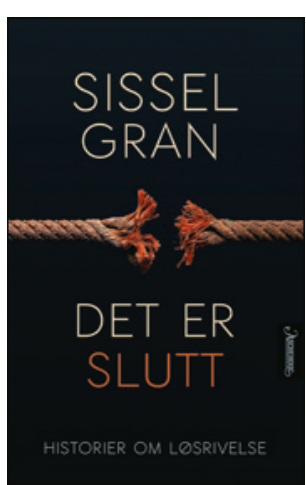

Sissel Gran

Det er slutt

Historier om løsrivelse. $236 \mathrm{~s}$

Oslo: Aschehoug, 2016. Pris NOK 329

ISBN 978-82-03-29542-3

Samlivsboken til psykolog og parterapeut Sissel Gran, Det er slutt, har nå ligget oppslått rundt omkring $\mathrm{i}$ hjemmet vårt de siste ukene på stuebordet, ved hodeputen, på nattbordet og ved godstolen. Han som har vært min mann i snart 30 år, har sett litt nervøst på meg og lurt på hva den handler om. På den måten har vi to, parallelt med min lesing, hatt noen veldig gode samtaler og refleksjoner omkring vårt eget samliv.

Gjennom 13 kapitler med forskjellige velvalgte temaer og overskrifter tar forfatteren oss med inn i historiene og samlivsbruddene til «utbryterne» hun har dybdeintervjuet.

Hun ønsker å formidle historiene til dem som i årevis har slitt med å få et parforhold til å fungere, men som til slutt har gitt opp og dermed påtatt seg det store og tunge ansvaret det er å gå. Hun mener, og det er sannsynligvis helt riktig, at dette er en undervurdert, noe ukjent og svært smertefull prosess som det er viktig å få belyst.

Hun har ønsket og også lyktes med å komme bakom de ofte ganske overfladiske forklaringene av typen «vi vokste fra hverandre» eller «vi var så forskjellige». Med gode eksempler og henvisninger til skjønnlitteratur og faglitteratur, sitt eget liv, foreldrenes samliv samt film og drama syr hun sammen temaene og kapitlene på en veldig god måte.

Vi får en fin dose tilknytningsteori som grunnlag for resten av boken allerede i kapitel 2, og dette går som en rød tråd gjennom alle kapitlene.

For meg som terapeut og psykiater ble Det er slutt en oppvekker når det gjelder å vektlegge og utforske kvaliteten på pasientenes parforhold og samliv i mye større grad i klinisk praksis. Poliklinikkene oversvømmes av pasienter i alle aldre som henvises for «angst og depresjon», og vi terapeuter rapporterer ofte nokså kort i journalen at pasienten er singel, gift, samboer eller skilt, uten alltid å gå i dybden på dette. Jeg tenker at mange kan slite med å være åpne om problemer i parforholdet som bakenforliggende belastning dersom temaet samliv ikke eksplisitt bringes på bane.

Jeg har anbefalt boken til venner, mine egne voksne barn, kolleger og min egen partner.

Jeg har bare én liten bekymring når det gjelder lesere uten spesiell teoretisk psykologisk ballast, og det er den «psykologiserte» språkdrakten. Den kan virke fremmed, og jeg frykter at en del lesere som virkelig kunne hatt nytte av boken vil dette av lasset.

Sissel Gran er allerede meldt inn til min ledelse som en ønsket foredragsholder på et dagsseminar i løpet av neste år, og jeg håper det lar seg realisere.

\section{Kognitiv terapi ved somatisk sykdom}

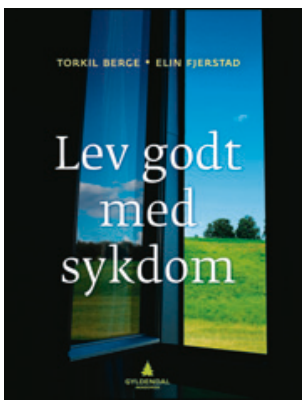

Torkil Berge, Elin Fjerstad

Lev godt med sykdom

205 s, ill. Oslo: Gyldendal Akademisk, 2016.

Pris NOK 349

ISBN 978-82-05-49150-2

Berge \& Fjerstad har skrevet flere bøker om kognitiv terapi, og de har mye kompetanse i dette. Denne handler om teknikker pasienter med forskjellige somatiske sykdommer kan anvende. Den består av seks deler og 14 kapitler. Del 1 dreier seg om å tåle sykdom i kroppen og ta vare på livet, del 2 om tankens makt, del 3 om kroppen i endring, del 4 om følelsenes kraft, del 5 om handling og kommunikasjon og del 6 om å leve godt sammen med somatisk sykdom.

Sentralt står den såkalte diamanten, det vil si de fire delene tanker, følelser, kropp og handling og den gjensidige påvirkningen mellom disse. En annen sentral fremstilling er den såkalte $\mathrm{ABC}$-modellen for tankesortering, hvor A er situasjon, B tanker og C følelser og handlinger.

Lev godt med sykdom er skrevet i du-form, forfatterne henvender seg direkte til den tenkte pasient. Det er en form som kan fungere, men det er mulig at de som ikke har de aktuelle lidelsene, kan oppleve at teksten er mindre aktuell.

Det er et spørsmål om ikke markedet snart er mettet med bøker om selvhjelp, spesielt i form av kognitiv terapi. Det er tross alt ganske like metoder som anvendes.

Denne anmelderen sitter igjen med et inntrykk av at boken er litt preget av quick-fix, da det kan synes som om ganske enkle grep raskt vil gjøre det lett å leve med alvorlig somatisk sykdom. Selv om mange pasienter har en imponerende evne til å mestre sykdom, er det også mange som sliter med langvarig smerte og fortvilelse. Dette gjelder både dem som har fått livet snudd på hodet etter å ha blitt alvorlig syke, men også psykiatriske pasienter som har fått alvorlig somatisk sykdom i tillegg. Det tunge lidelsestrykket man ofte ser i den somatiske klinikken, kommer i liten grad frem. Det kunne godt ha stått et sted at følelseslivet er mye mer komplisert enn det som svarer til de enkle modellene. Ikke minst spiller pasientens historie en betydelig rolle for evnen til å mestre sykdom.

Det er en stor svakhet at over $40 \%$ av referansene er til forfatternes egne publikasjoner, spesielt fordi nesten ingen av disse er originalpublikasjoner.

Forfatternes har stilet boken til pasienter, men i håp om at den også er nyttig for hjelpere, som pårørende eller helsepersonell. Det er sikkert mange pasienter og pårørende som kan ha nytte av å lese den. For helsepersonell som har noe kunnskap om kognitiv terapi, er nok utbyttet begrenset.

\title{
Øivind Ekeberg
}

Spesialrådgiver, Klinikk psykiske helse og avhengighet Oslo universitetssykehus 